\title{
RESPONSI NILAI-NILAI ISLAM DALAM PENGEMBANGAN KAWASAN PENDIDIKAN: STUDI RESPONSIVE ENVIRONMENT PADA PESANTREN MADANI ALAUDDIN, PAO-PAO MAKASSAR
}

\author{
Mukhlishah Sam ${ }^{1 *}$, Samiang Katu ${ }^{2}$, Ahmad Ibrahim Rahmani ${ }^{1}$ \\ ${ }^{1}$ Jurusan Teknik Arsitektur \\ Fakultas Sains dan Teknologi UIN Alauddin Makassar \\ Jl. Sultan Alauddin No. 63, Kabupaten Gowa, Sulawesi Selatan. 92113 \\ ${ }^{2}$ Jurusan Studi Agama-Agama \\ Fakultas Ushuluddin dan Filsafat UIN Alauddin Makassar \\ Jl. Sultan Alauddin No. 63, Kabupaten Gowa, Sulawesi Selatan. 92113 \\ *E-mail: mukhlishah.sam@uin-alauddin.ac.id
}

\begin{abstract}
Abstrak: Kawasan pendidikan merupakan salah satu tulang punggung dalam dunia pendidikan untuk mencerdaskan anak bangsa. Dalam perkembangannya, kawasan pendidikan mengalami transformasi yang sangat pesat mengikuti dengan kemajuan zaman. Namun di dalam kondisi perkembangan yang terus berjalan tidak diiringi dengan pengembangan nilainilai keislaman, khusunya pada kawasan pendidikan Islam. Dalam penelitian ini kami menganalisis tata ruang Kawasan Pendidikan Pesantren Madani Alauddin Pao-Pao baik secara tata massa bangunan maupun dari segi kondisi suasana pada ruang-ruang kelas yang berdasarkan nilai ajaran Islam. Kondisi yang ada saat ini pengaturan tata massa bangunan Kawasan Pesantren Madani Alauddin Pao-Pao seperti halnya tambal sulam pada pakaian. Untuk menjadikan Pesantren Madani Alauddin Pao-Pao perlu dilakukan penataan ulang kawasan pendidikan, sehingga kawasan pendidikan yang ada memiliki nilai-nilai Islam di dalamnya. Metode digunakan adalah studi responsive environment yang disandingkan dengan nilai-nilai ajaran Islam. Dari studi tersebut dihasilkan bahwa yang menjadi focal point dari Kawasan Pesantren Madani Alauddin Pao-Pao adalah masjid, sehingga nilai yang pertama hadir dari kawasan ini adalah ketakwaan, kepatuhan. Setelah masjid keberadaan gedung pengelola sebagai bagian dari sistem administrasi kawasan pesantren dan sebagai controlling untuk pengguna kawasan. Selanjutnya, gedung pembelajaran dan diikuti oleh gedung-gedung pendukung lainnya.
\end{abstract}

Kata Kunci: kawasan pendidikan, nilai-nilai Islam, responsive environment

\section{PENDAHULUAN}

$\mathrm{P}$ erkembangan kawasan pendidikan pada umumnya diharapkan menjadi suatu lingkungan binaan yang memiliki karakter serta mandiri, dan menuntun sebuah model pengembangan yang direncanakan dengan dasar pertimbangan yang holistik. Pada khususnya lingkungan pendidikan pesantren atau madrasah, model pengembangan kawasannya masih membutuhkan perencanaan yang baik untuk mencapai tujuan pendidikan yakni terciptanya Insan Qur'ani yang intelektual namun tidak lepas dari nilai-nilai dasar keIslaman. Misi utama pendidikan Islam adalah merealisasikan keimanan dan ketakwaan penuh pada Allah SWT di tingkat individual maupun 
komunitas. Sehingga pendidikan Islam senantiasa dijalankan atas dasar dua nilai utama, yakni nilai ilahiyah dan nilai isnaniah.

Berdasarkan Peraturan Menteri Pekerjaan Umum Nomor: 06/PRT/M/2007 tentang Pedoman Umum Rencana Tata Bangunan dan Lingkungan, Penataan Kualitas Lingkungan merujuk pada upaya rekayasa elemen-elemen kawasan yang sedemikian rupa sehingga tercipta suatu kawasan atau subarea dengan sistem lingkungan yang informatif, berkarakter khas, dan memiliki orientasi tertentu. Konsep identitas lingkungan, yaitu perancangan karakter (jati diri) suatu lingkungan yang dapat diwujudkan melalui pengaturan dan perancangan elemen fisik dan nonfisik lingkungan atau subarea tertentu. Pengaturan ini terdiri atas tata karakter bangunan/lingkungan (Built-in Signage and Directional System), yaitu pengolahan elemen-eleman fisik bangunan/lingkungan untuk mengarahkan atau memberi tanda pengenal suatu lingkungan/bangunan, sehingga pengguna dapat mengenali karakter lingkungan yang dikunjungi atau dilaluinya sehingga memudahkan pengguna kawasan untuk berorientasi dan bersirkulasi.

Tata penanda identitas bangunan, yaitu pengolahan elemen-eleman fisik bangunan/lingkungan untuk mempertegas identitas atau penamaan suatu bangunan sehingga pengguna dapat mengenali bangunan yang menjadi tujuannya. Tata kegiatan pendukung secara formal dan informal (Supporting Activities), yaitu pengolahan secara terintegrasi seluruh aktivitas informal sebagai pendukung dari aktivitas formal yang diwadahi dalam ruang/bangunan, untuk menghidupkan interaksi sosial dari para pemakainya.

Dalam mengokupasi ruang, manusia mempersepsikan lingkungan dalam tiga proses yaitu kognisi (cognitive), afeksi (affective) serta kognasi (cognative). Proses kognisi meliputi proses penerimaan, pemahaman, dan pemikiran tentang suatu lingkungan. Proses afeksi meliputi proses perasaan dan emosi, keinginan, serta nilai-nilai tentang lingkungan. Sementara proses kognasi meliputi munculnya tindakan, perlakuan terhadap lingkungan sebagai respon dari proses kognisi dan afeksi (Zohrah \& Hartono, 2005). Di sisi lain, sebuah lingkungan dapat dilakukan studi dalam pendekatan responsi lingkungan.

Studi responsive environment dilakukan dalam rangka menilai bagaimana kualitas lingkungan yang mudah dimengerti oleh penggunanya. Teori ini menekankan bahwa lingkungan binaan (arsitektur dan elemen bangunan lainnya) adalah bagian yang tidak terpisahkan yang memberikan kontribusi terhadap kehidupan manusia (Kamil, 2017). Beberapa kriteria penilaian yaitu adanya arahan ke mana pengunjung dapat pergi dan ke mana pengunjung dilarang, disebut permeability. Tingkatan ruang yang dapat diakses oleh pengunjung yang disebut variety. Kemudahan bagi pengunjung untuk memahami fungsi dan kegunaan ruang disebut legability. Kemungkinan penggunaan ruang untuk fungsi yang berbeda disebut robustness. Kualitas detail bentuk visual yang memberikan kesadaran akan fungsi yang tersedia disebut visual proprietness. Kualitas pengalaman ruang yang akan diperoleh pengunjung disebut richess. Eksistensi pengunjung dalam penggunaan ruang disebut personalitation.

Arsitektur berdasarkan ajaran Islam adalah arsitektur yang berangkat dari konsep pemikiran Islam. Inti dari ajaran Islam adalah al-Qur'an dan Hadits. Konsep arsitektur Islam adalah olahan yang mempunyai sifat tidak merusak alam dan harus sesuai dengan apa yang dibutuhkan Dalam beraktivitas apapun termasuk dalam merancang, seorang arsitek muslim harus selalu berpegang kepada al-Qur'an dan as-Sunnah agar hasil rancangannya memberikan manfaat (Akromusyuhada, 2019). Konsep lainnya adalah 
konsep bukan muhrim, dapat diterapkan dalam perencanaan pembedaan antara laki-laki dan perempuan. Hal ini sesuai dengan norma dalam Islam yang menjelaskan wanitawanita yang tidak boleh dikawini dalam Islam, misalnya ibu kandung, anak perempuan, dan sebagainya (Heryati, 2019).

Pesantren Madani Alauddin Pao-Pao sebagai salah satu kawasan pendidikan terpadu yang sekaligus menjadi laboratorium pengajaran bagi Fakultas Tarbiyah dan Keguruan UIN Alauddin Makassar. Sebagai suatu lingkungan binaan yang Islami, Pesantren Madani Alauddin berupaya mewujudkan nilai-nilai dasar Islam dalam kegiatan belajar mengajarnya. Namun upaya internalisasi nilai Islam tersebut dalam setiap aktivitas dalam lingkungan pesantren tersebut masih perlu ditingkatkan dengan sebuah model pengembangan lingkungan pesantren yang lebih terencana dan lebih responsif sehingga dapat mendukung proses transfer nilai di setiap aspek kepada peserta didik yang beraktivitas di lingkungan pesantren. Atas dasar pemikiran ini diperlukan sebuah studi mendalam yang fokus mengkaji tentang "Responsi Nilai-Nilai Islam dalam Pengembangan Kawasan Pendidikan". Kajian ini direncanakan menggunakan teori responsive environment untuk menemukan model pengembangan kawasan yang tepat untuk kasus Pesantren Madani Alauddin, Pao-Pao-Makassar.

\section{METODE PENELITIAN}

Penelitian ini menggunakan studi responsive environment sebagai dasar kajian. Lokasi studi yaitu Pesantren Madani Alauddin Pao-Pao Makassar. Penelitian ini bersifat kualitatif. Penelitian kualitatif digunakan untuk mendapatkan data yang mendalam, suatu data yang mengandung makna. Sebagaimana prosedur perolehan data penelitian kualitatif, data studi kasus diperoleh dari wawancara, observasi, dan arsip (Yeti, 2018) Pada penelitian ini, dengan metode penelitian kualitatif studi kasus, peneliti sebagai instrumen utama penelitian akan turun langsung ke lapangan guna mendapatkan data dan realita di lapangan.

Penelitian ini dilakukan dengan tahapan awal yakni mengidentifkasi aspek-aspek kawasan pendidikan. Proses identifikasi kawasan dengan menilai unit analisis elemen pembentuk ruang kawasan/kota menurut Shirvani (1985) antara lain: (1) Konservasi tata guna lahan (Land use); (2) Bentuk dan massa bangunan (Building form and massing); (3) Sirkulasi dan Parkir (Circulation and parking); (4) Ruang terbuka (Open space); (5) Jalur pedestrian (Pedestrian ways); (6) Penanda (Signages); (7) Kegiatan pendukung (Activity Support). Masing-masing unit Analisa akan dibahas dengan menggunakan sudut lingkungan yang responsif terhadap nilai-nilai Islam. Desain penelitian ditunjukkan pada Gambar 1.

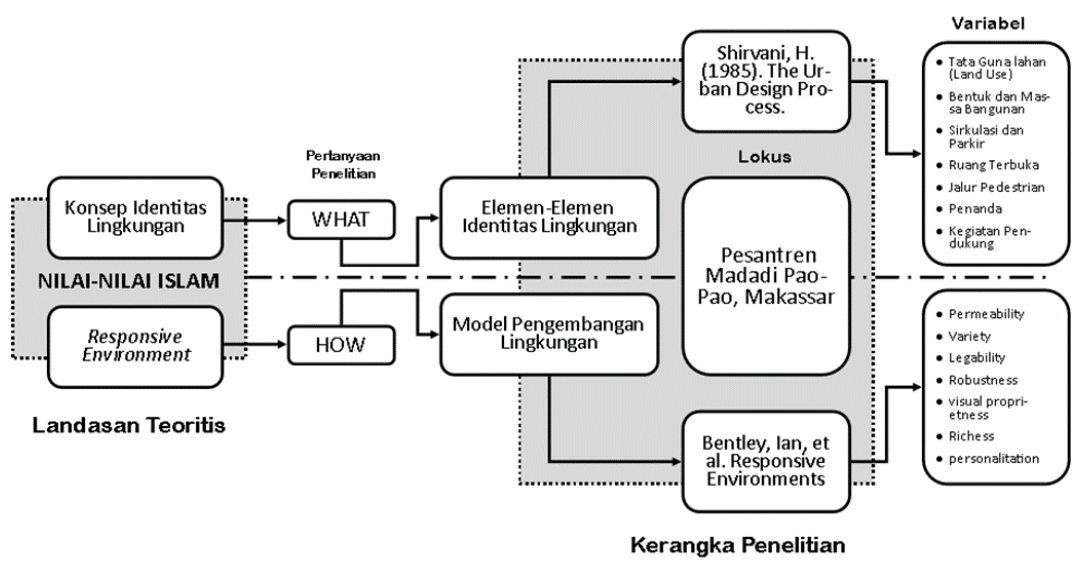

Gambar 1. Desain penelitian 


\section{HASIL DAN PEMBAHASAN}

\section{Elemen Identitas Lingkungan Pesantren Madani Alauddin Pao-Pao}

Tata Guna Lahan, konsep peruntukan lahan yang dikembangan di area Pesantren Madani Pao-Pao teridentifikasi masih sporadis dengan menyesuaikan kebutuhan pada jangka waktu tertentu. Hal ini terlihat dari master plan (Gambar 2) kawasan yang belum tertata dengan baik. Bentuk dan Massa Bangunan pada Kawasan Pesantren Madani Pao-Pao masih tidak memberikan gambaran tentang suatu kawasan pendidikan Islam. Bentuk tampilan bangunan yang ada, tidak berbeda dengan bentuk tampilan bangunan pendidikan pada umumnya, baik dari segi warna maupun dari segi penggunaan material khusus. Sirkulasi dan Parkir pada Kawasan Pesantren Madani Pao-Pao masih menyatu. Belum ada pembagian ruang yang jelas antara sirkulasi orang dan kendaraan. Ruang Terbuka. Terdapat empat fungsi RTH yaitu fungi ekologi, fungsi sosial budaya, fungsi ekonomi dan fungsi estetika. Fungsi ekologi sebagai pengatur iklim mikro yang berdampak pada lancarnya sirkulasi udara dan air secara alami, sebagai peneduh dan menghasilkan oksigen. Fungsi sosial dan budaya sebagai media komunikasi warga, tempat rekreasi dan wadah objek pendidikan (Pradani, 2020).

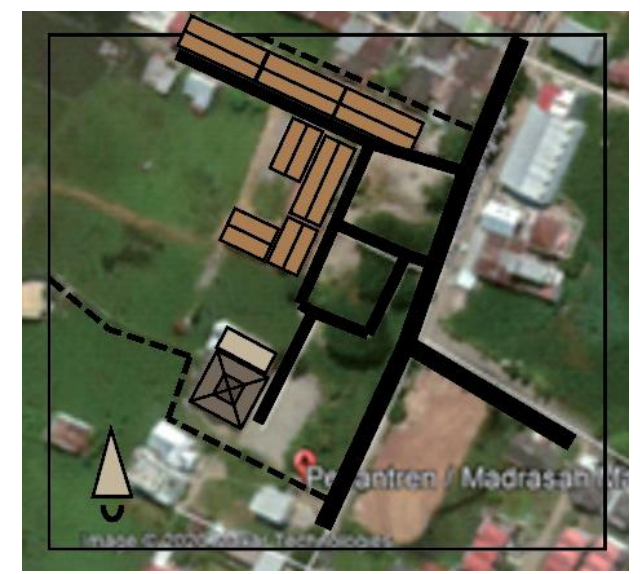

Gambar 2. Site plan Pesantren Madani Pao-Pao (Google Earth, 2020)

Luas lahan Kawasan Pesantren Madani Pao-Pao \pm 6 ha. Dari luas keseluruhan kawasan, 30\% luas lahan yang terbangun adalah area terbangun yang meliputi: masjid, kantor, ruang kelas, lapangan olahraga dan parkiran. Sedangkan sisanya $70 \%$ adalah area pengembangan. Jalur Pedestrian. Kawasan pesantren madani tidak memiliki jalur pedestrian, hal ini disebabkan pada Kawasan Pesantren Madani, tata massa bangunan masih tidak teratur. Penanda. Kawasan Pesantren Madani Alauddin Pao-Pao telah memiliki beberapa penanda yang digunakan untuk menunjukkan tingkatan kelas pada setiap kelas berupa papan kelas yang ditempel/digantung pada pintu kelas, papan penanda laboratorium dan ruang Kelapa Sekolah, serta ruang administrasi. Kegiatan Pendukung, di dalam Kawasan Pesantren Madani Pao-Pao pada tahun 2020 telah ada dua penambahan bangunan yang menjadi kegiatan pendukung dari kawasan pendidikan berupa gedung pusat pelatihan guru dan rumah jabatan Rektor UIN Alauddin Makassar.

\section{Pengembangan Pesantren Madani Pao-Pao}

Perkembangan pembangunan Pesantren Madani Pao-Pao dalam 7 tahun tahun terakhir dimulai dari tahun 2013 dengan pembangunan gedung masjid, ruang Kepala Sekolah, perpustakaan, dan ruang kelas untuk tingkat SMP, kemudian di tahun 2015 
berkembang dengan penambahan gedung untuk ruang guru dan ruang koperasi sekolah, lalu di tahun 2017 kelas untuk tingkat SMA, tahun berikutnya 2019 dibangun pula gedung asrama untuk siswa. Dan terakhir di tahun 2020 dibangun lagi tambahan ruang kelas baru, gedung pelatihan guru dan rumah jabatan rektor UIN Alauddin Makassar (Gambar 3).
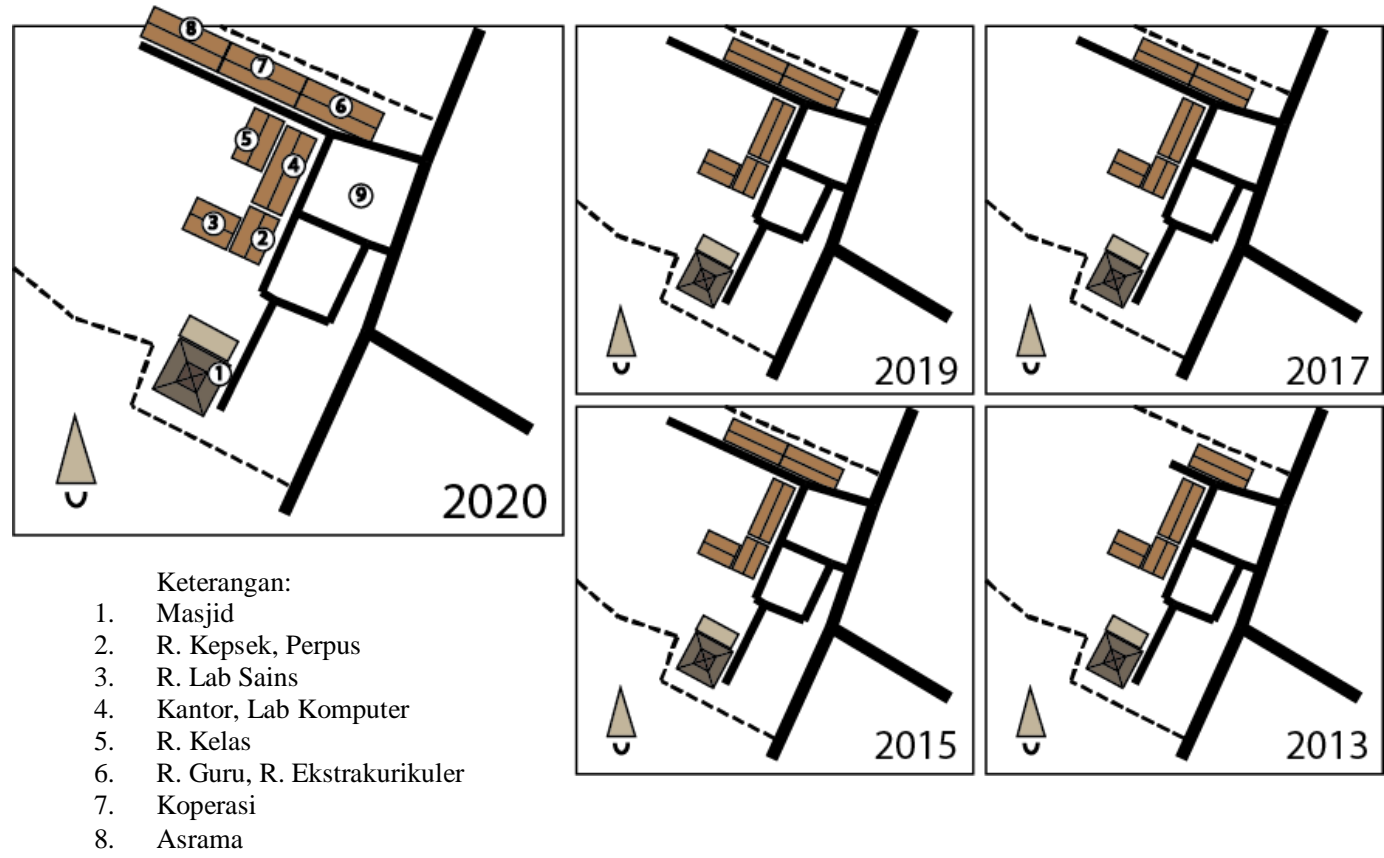

Gambar 3. Pengembangan Pesantren Madani Pao-Pao (Muhklisah, 2020)

\section{Studi Analisis Rensponsi Nilai-Nilai Ajaran Islam pada Kawasan Pesantren Madani Alauddin Poa-Pao.}

\section{Permeability}

Permeabilitas sebagai parameter untuk mengukur sejauh mana konfigurasi ruang dalam menyediakan pilihan dalam menempuh perjalanan dan aksesibilitas. Parameter yang diukur dalam permeabilitas sebagai hasil dari interaksi antara individu dengan sistem ruang (Permana et al., 2020). Kawasan Pesantren Madani Alauddin Pao-Pao dalam membangun dan membentuk karakter kawasan pendidikan yang berdasarkan nilai-nilai ajaran Islam. Permeabilitas membantu pengguna Kawasan Pesantren Madani Alauddin Pao-Pao mengetahui batasan-batasan apa saja yang boleh dan tidak boleh dilakukan selama berada di Kawasan Pesantren Madani Alauddin Pao-Pao.

Dalam ajaran Islam, batasan yang dimaksudkan adalah berupa hijab antara laki-laki dan perempuan. Abu Daud dalam riwayatnya; Rasullah bersabda:

$$
\begin{aligned}
& \text { سنين عشر بناء ا هم و عليها هم بو ضر وا سنين سبع بناء ا هم وة الصلا با كم او لاد وا مر } \\
& \text { جع لمضا ا فى بينهم قوا وفر }
\end{aligned}
$$

Artinya:

"suruhlah anak-anak mu shalat ketika berusia tujuh tahun. Dan pukullah mereka karena tidak mau shalat pada usia sepuluh tahun. Dan pisahkanlah tempat tidur mereka (antara yang laki-laki dan perempuan)" 
Dalam beberapa kitab menjelaskan pemisahan tempat tidur antara anak laki-laki dan perempuan bertujuan untuk membentengi pribadi anak dari perilaku atau tindakan yang tidak baik.

\section{Variety}

Merupakan tingkatan ruang yang dapat diakses oleh pengunjung. Pada Kawasan Pesantren Madani Pao-Pao tingkatan akses hanya dibatasi antara akses pengunjung/tamu oleh pengaturan kebijakan keamanan sekolah, dalam hal ini dibantu oleh satuan pengamanan sekolah. Namun dalam hal perencanaan lingkungan fisik, zona-zona yang dapat diakses dan tidak, masih belum dibatasi dengan jelas. Hal ini terlihat dari pola sirkulasi kendaraan masuk keluar area sekolah masih belum diarahkan dan jalur sirkulasi pejalan kaki dalam lingkungan sekolah pun belum dipisahkan antara tamu dan pengelola sekolah serta siswa. Selain pola sirkulasi kendaraan, pembatasan akses antara pengelola sekolah dan siswa/siswi belum terlihat jelas. Sehingga kesan yang terlihat adalah kurangnya rasa penghargaan dan penghormatan terhadap orang tua (guru dan pengelola sekolah).

Prinsip Habluminannas dan Habluminallah diaplikasikan dengan keberadaan masjid di kawasan pendidikan sebagai focal point (bangunan utama dan bangunan pertama yang ditemukan/dilihat ketika memasuki Kawasan Pesantren Madani Pao-Pao. Hal ini berdasarkan makna dari kata masjid. Masjid secara etimologis bermakna sujud berarti taat, tunduk, patuh, takzim dan penuh rasa hormat. Sehingga maksud dari desain kawasan yang menjadikan masjid sebagai focal point dari Kawasan Pendidikan Pesantren Madani Pao-Pao diharapkan melahirkan generasi Qur'ani yang taat, patuh, tunduk terhadap segala peraturan dan perintah Allah SWT, dan penuh rasa hormat kepada setiap orang, khusunya orang tua.

\section{Legability}

Legability atau kemudahan bagi pengunjung untuk memahami fungsi ruang. Kawasan Pendidikan Pesantren Madani Pao-Pao sudah memiliki penanda pada setiap ruang. Namun masih memerlukan sedikit polesan sehingga penanda lebih mudah terlihat dan terbaca oleh pengguna. Allah SWT tidak menyukai kesulitan, hal ini sesuai dengan ayat-ayat Al-Qur'an antara lain pada Q.S Al-Baqarah ayat 2 dan 5.

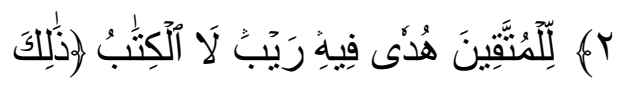

Terjemahnya:

"inilah kitab (Al-Qur'an) tidak ada keraguan di dalamnya (sebagai) petunjuk bagi orang-orang bertaqwa".

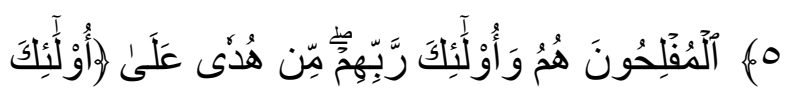

Terjemahnya:

"mereka itulah di atas petunjuk dari Tuhan (pencipta) mereka dan mereka itu merekalah orang-orang yang beruntung" 
Berdasarkan dua ayat tersebut, sangat jelas bahwa, Barang siapa yang mengikuti petunjuk yang sudah ada tidak akan tersesat. Kondisi ini berlaku di Kawasan Pendidikan Pesantren Madani Pao-Pao, ketika pengguna mengikuti petunjuk/penanda yang ada di kawasan tersebut, pengguna tidak akan salah dalam mencari tempat yang dituju.

\section{Robustness}

Rekonsiliasi fungsi ruang pada bangunan eksiting Pesantren Madani Pao-Pao menjadi sangat penting sehingga proses penataan ruang berdasarkan fungsi, zonasi, batasan hijab dapat tercapai. Hal ini sesuai dengan ajaran Islam yang tidak membenarkan berperilaku mubadzir, sesuai dengan ayat al-Qur'an surah al-A'raaf ayat 31.

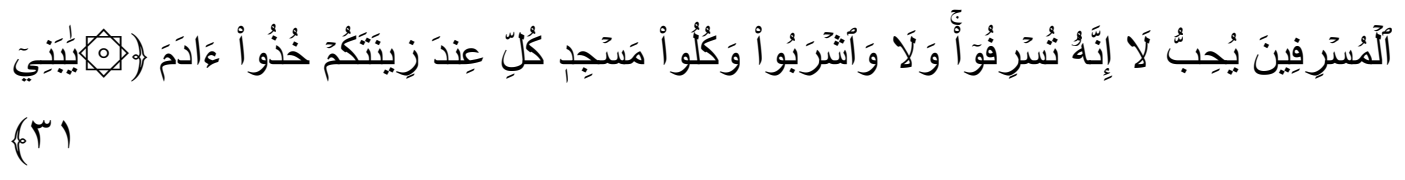

Terjemahnya:

"wahai anak cucu Adam! Pakailah pakaianmu yang bagus pada setiap (memasuki) masjid, makan dan minumlah, tetapi jangan berlebihan. Sesungguh, Allah tidak menyukai orang yang berlebih-lebihan.

\section{Visual Propriateness}

Kesadaran pengunjung akan fungsi ruang yang direncanakan juga sangat penting hal ini dapat ditunjang dengan pengadaan penanda khusus yang memberikan kekuatan visual terhadap fungsi ruang.

\section{Richness}

Kualitas pengalaman ruang yang dirasakan oleh pengguna ruang Pesantren Madani Pao-Pao akan serta merta dicapai dengan peningkatan kualitas visual yang ada pada setiap ruang. Desain yang digunakan dalam membangun suasana ruang dalam Kawasan Pesantren Madani Alauddin Pao-Pao harus membangun suasana keislaman. Penggunaan meja dan kursi tunggal atau masing-masing setiap peserta didik, adanya jarak antara meja yang satu dengan yang lainnya sehingga ada hijab yang terbentuk sebagai salah satu bentuk desain ruang kelas.

\section{Personalitation}

Ruang personal sangat erat dengan fungsi teritorialitas ruang sebagai proses interaksi antara naluri dan pembelajaran. Teritorialitas mampu memetakan jenis perilaku yang diantisipasi, siapa yang dihadapi, dan bagaimana statusnya. Manusia lebih menjadi fleksibel berkenaan dengan penggunaan teritori (Sari et al., 2019). Peningkatan eksistensi pengguna ruang dapat dimaksimalkan dengan ploting ruang yang menampilkan karakteristik yang Islami sesuai dengan nilai-nilai yang diajarkan pada Pesantren Madani Pao-Pao. Ploting ruang ini bertujuan memberikan informasi kepada pengguna ruang bahwa di dalam ruang ada aturan-aturan yang berlaku. Seperti penggunaan warna pink untuk siswa perempuan dan penggunaan warna biru untuk siswa laki-laki. Perbedaan warna ini bisa diterapkan pada penggunaan furniture, sehingga pada saat siswa-siswi masuk di kelas mereka sudah pahan di mana area mereka berdasarkan gender. 
Berdasarkan pembahasan elemen lingkungan Kawasan Pesantren Madani Pao-Pao dan studi lingkungan responsif, maka dapat diajukan rekomendasi model pengembangan lingkungan Kawasan Pesantren Madani Pao-Pao (Gambar 4) yaitu:

1. Zonasi lingkungan Pesantren Madani Pao-Pao menjadi 4 zona yang dapat memberikan respon terhadap kebutuhan tata guna lahan yang merefleksikan nilai-nilai islam, meliputi:

a. Zona Publik, ada beberapa bagian publik yang dipisahkan berdasarkan gender yaitu; toilet, tempat wudu;

b. Zona Edukasi, sebagai area utama kegiatan pembelajaran yang sebagian aksesnya telah dibatasi dengan pemisahan zona kegiatan antara siswa laki-laki dan siswa perempuan. Pemisahaan zona yang diterapkan di area kelas dengan menggunakan warna sebagai indikator, penggunaan kursi dan meja tunggal;

c. Zona Pengelola, area kegiatan pengelola Pesantren Madani Pao-Pao untuk memudahkan kegiatan administrasi dan kontrol bagi peserta didik;

d. Zona Pengembangan, area yang diperuntukan untuk pengembangan gedung penunjang kegiatan pembelajaran.

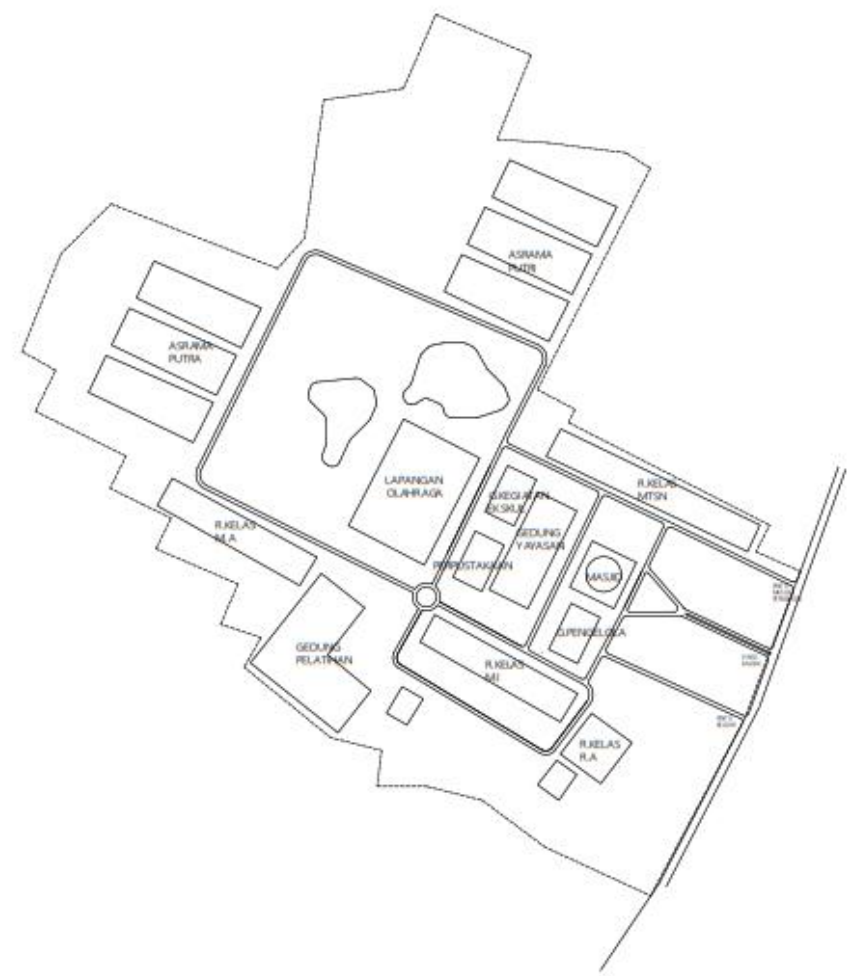

Gambar 4. Tata guna lahan di lingkungan Pesantren Madani (Penulis, 2020)

2. Ploting ulang fungsi ruang Pesantren Madani Pao-Pao dengan melakukan rekonsiliasi fungsi ruang yang ada, sehingga dapat merespon nilai-nilai Islam khususnya hablumminannas.

3. Penaataan ulang alur sirkulasi (Gambar 5) dan parkir di lingkungan Pesantren Madani Pao-Pao agar lebih efektif dalam menerapkan nilai-nilai Islam. 


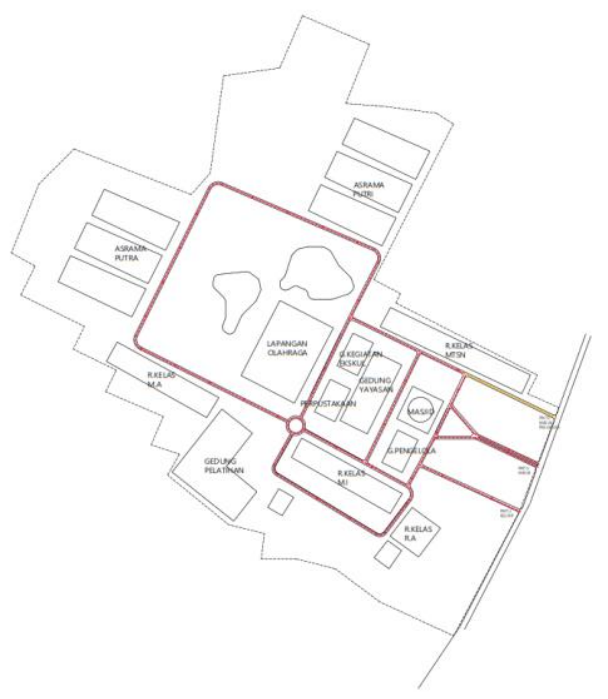

Gambar 5. Pola sirkulasi Kawasan Pesantren Madani Alauddin Pao-Pao (Penulis, 2020)

4. Perlunya peningkatan kualitas visual melalui desain penanda bangunan yang memiliki karakteristik yang sesuai dengan nilai-nilai Islam.

\section{KESIMPULAN}

Kawasan Pesantren Madani Alauddin Pao-Pao masih perlu dilakukan penataan ulang sehingga kawasan pendidikan ini lebih mencerminkan nilai-nilai Islam di dalamnya. Beberapa rekomendasi model pengembangan yaitu: (1) Perlunya membagi zonasi lingkungan Pesantren yang dapat memberikan respon terhadap kebutuhan tata guna lahan yang merefleksikan nilai-nilai islam; (2) Ploting ulang fungsi ruangan pesantren; (3) Penataan ulang alur sirkulasi; dan (4) Peningkatan kualitas visual dengan karakteristik nilai-nilai Islam.

\section{DAFTAR PUSTAKA}

Akromusyuhada, A. (2019). Penerapan konsep arsitektur islam pada sarana dan prasarana pendidikan: Tinjauan Peraturan Menteri Pendidikan Nasional Republik Indonesia Nomor 24 Tahun 2007 tentang Standar Sarana dan Prasarana untuk SD/MI, SMP/Mts, dan SMA/MA. Jurnal Tahdzibi, 4(1), 4148. Doi. 10.24853/tahdzibi.4.1.41-48.

Heryati. (2019). Konsep Islam dalam Pasang Ri Kajang sebagai Suatu Kearifan Lokal Tradisional dalam Sistem Bermukim. [Karya Ilmiah]. Gorontalo: Jurusan Arsitektur Universitas Negeri Gorontalo.

Kamil, E. M. (2017). Pengenalan metoda disain dan penerapannya pada studio perancangan arsitektur. Jurnal Arsir, 1(1), 19-29.

Permana, A. Y., Permana, A. F. S., \& Andriyana, D. (2020). Konfigurasi ruang berdasarkan kualitas konektivitas ruangan dalam perancangan kantor: Space syntax analysis. Jurnal Arsitektur ZONASI, 3(2), 155-170. Doi. 10.17509/jaz.v3i2.25893.

Pradani, S. W. (2020). Perilaku masyarakat di ruang terbuka publik alun- alun Kabupaten Blora. Jurnal Tata Loka, 22(1), 50-60.

Sari, D. P., \& Pramitasari, D. (2019). Perilaku pemilihan tempat duduk pada perpustakaan Jurusan Teknik Arsitektur Universitas Gadjah Mada. Jurnal Arsitektur Grid - Journal of Architecture and Built Environment, 1(1), 20-29.

Yeti, A. E. (2018). Kajian arsitektur perilaku untuk ruang laktasi di ruang publik. Jurnal Arsitektur dan Perencanaan (JUARA), 1(2), 168-182. Doi. 10.31101/juara.v1i2.771.

Zohrah, L., \& Hartono, R. (2005). Studi perilaku mahasiswa arsitektur terhadap kantin Jurusan Teknik Arsitektur Fakultas Teknik Universitas Lambung Mangkurat. Jurnal Info Teknik, 6(1), 21-32. 